\title{
İlkokul Türkçe Ders Kitaplarındaki Metinlerde Kültürel Değerler ${ }^{1}$
}

\author{
DOI: $10.26466 /$ opus.902826
}

\author{
$*$ \\ Bașak Kasa Ayten * \\ * Dr. Öğr. Üyesi, İnönü Üniversitesi, Eğitim Fakültesi, Malatya/TÜRKIYE \\ E-Posta: basak.kasa@inonu.edu.tr \\ ORCID: $\underline{0000-0001-5926-3380}$
}

\begin{abstract}
Öz
Dil bir kültür aktarıcısıdır. Dil sayesinde toplumun kimliğini ve davranış özelliklerini yansıtan kültür ve kültürel değerler gelecek kuşaklara aktarılır. Türkçe dersi hem dil becerilerini geliştirmede hem de kültürel değerleri kazandırmada öncelikli bir derstir. Dilin kazandırılmasında rol sahibi olan Türkçe dersinde kültürel değerlerin incelenmesi dil kültür ilişkisinin kurulması açısından önemlidir. Bu bağlamda çalışmada Türkçe ders kitaplarındaki metinlerde yer alan kültürel değerlerin incelenmesi amaçlanmaktadır. Çalışmada nitel araştırma yaklaşımı benimsenmiş ve doküman analizi yöntemi kullanılmıştır. Seçkisiz örnekleme yoluyla 2, 3 ve 4. sınıf Türkçe ders kitaplarından her biri farklı yayınevi olmak üzere her sinıf seviyesinden birer kitap seçilmiştir. Seçilen kitaplar içerik analiziyle analiz edilmiş ve "Türk Dili, Türk Tarihi, Şehirler, Sanat, Bağımsızlık Simgesi, Din, GelenekGörenek" olmak üzere 7 tema üzerinde veriler sınıflandırılmıştır. İncelenen kitaplarda en çok Türk Tarihi temasının vurgulandığı ve en çok 4. simıf ders kitabında kültürel değerlere rastlandığı sonucuna ulaşılmıştır. Bunun yan sıra bütün sinıflarda eşit düzeyde Bağımsızlık Simgesi teması vurgulanırken, 4. sınıfta Sanat ve Din teması diğer sınıflara göre daha çok vurgulanmıştır.
\end{abstract}

Anahtar Kelimeler: Türkçe ders kitapları, kültürel değerler, doküman analizi.

\footnotetext{
${ }^{1}$ Bu çalışma 2-4 Kasım 2017 tarihinde Inönü Üniversitesi'nde gerçekleştirilen 9. Uluslararası Dünya Dili Türkçe Sempozyumu'nda sunulan "ilkokul Türkçe Ders Kitaplarında Kültürel Değerler" adlı sözlü bildirinin verileri güncellenerek hazırlanmıştır.
} 


\title{
Cultural Values in the Texts in Primary School Turkish Course Textbooks
}

\begin{abstract}
Language is a culture transmitter. Thanks to the language, culture and cultural values that reflect the identity and behavioral characteristics of the society are passed on to future generations. Turkish lesson is a priority lesson in both developing language skills and gaining cultural values. Reviewing cultural values in the Turkish course, which has a role in language acquisition, is important in establishing the relationship between language and culture. In this context, it is aimed to examine the cultural values in the texts in Turkish textbooks. In the study, qualitative research approach was adopted and document analysis method was used. One book from each grade level was selected from the 2 nd, 3 rd and 4 th grade Turkish textbooks, each from a different publishing house, through random sampling. Selected books were analyzed with content analysis and data were classified on 7 themes: Turkish language, Turkish history, Cities, Art, Symbol of Independence, Religion, Tradition and Custom. It was concluded that the Turkish history theme was mostly emphasized in the analyzed books and cultural values were encountered mostly in the 4 th grade textbooks. In addition, while the Independence Symbol theme was emphasized equally in all textbooks, the theme of Art and Religion was emphasized more in the 4th grade textbook compared to the other textbooks.
\end{abstract}

Key Words: Turkish course textbook, cultural values, document analysis. 


\section{Giriş}

Değerler toplumdaki bireyleri ortak noktada birleştiren, bireylerin davranışlarını biçimlendiren, bireyleri iyiye, doğruya yönlendiren, ortak yaşantılar sonucu oluşan ölçütler, standartlardır. Demirhan İşcan (2019, s.31)'a göre bir değer; özgürce ve sonuçlarının getirileri düşünülüp seçilmeli, davranışa dönüştürülmeli, yaşamda yerini almalı ve etkileyeceği toplumdan onayını almalıdır. Toplum tarafından kabul görmüş ve içselleştirilmiş değerler, toplumu bir arada tutmaya ve toplumun sürekliliğini sağlamaya yarar. Benzer değerler toplumlar tarafından ortak kabul göreceği gibi bazen de değerler toplumdan topluma değişiklik gösterebilir. Bir toplumun kendine özgü özellikleri ancak başka toplumlarla bir araya geldiğinde açı̆̆a çıkar, ortak olmayan ve uyuşmayan özellikler kendini gösterir (Aksan, 2008, s.17). Bu durum kültürel bir çatışmadır ve değerlerin çatışmasıyla ortaya çıkar (Erkılıç, 2019, s.31).

Linton (1961; Akt. Kurt, 2004, s.26) kültürü "belli bir topluluğa ait öğrenilmiş davranış biçimleri" olarak tanımlamıştır. Bu davranış biçimleri toplumun özelliklerini yansitmaktadır. Tezcan (1987)'a göre de kültür bir toplumu yansitan toplumsal kalıtımıdır. Bir toplumun birlik beraberlik içerisinde yaşayabilmesi ve geçmişten getirdiği birikimi devam ettirebilmesi için kendi kültürüne sahip çıkması gerekmektedir.

Dil, tarih, töreler, örf ve adetler, duygu ve düşünceler, aile, akrabalık, din, devlet, yönetim, giyim kuşam, yerleşme, sanat, bilim, eğitim, ahlak, teknoloji, ekonomi kültürü oluşturan kültürel ögelerdir (Uygur, 2007, s. 56; Güvenç, 2002; Torun, 2006, s.24). Bu kültür ögeleri toplumun hem geçmişini korur hem de geleceğini şekillendirir hem de kimliğini oluşturur. Toplumun dilinden dinine, tarihî eserlerinden tarihî olaylara, yemeğinden giyim tarzına yaşayan bütün kültürel ögeler toplumun kendi kültürel değerlerini oluşturur (Kasa Ayten, 2019, s.308). Bir toplumun değer verdiği bazı sosyal, tarihî ve düşünce değerleri zamanla o toplumun kültürel değerleri haline gelir (Özkul, 2013, s.33). Dil, tarih, edebiyat, Türk musikisi, Türk plastik sanatları, Türk şehirleri de Türk toplumunun kültürel değerleridir (Kaplan, 1987).

Diline, tarihine, edebiyatına, sanatına, gelenek ve göreneklere bağlı bireyler yetiştirmek için toplumdaki kültürel değerlere önem verilmesi ve öğrencilere bu değerlerin aktarılması gerekmektedir. Kültürel 
değerlerine sahip çıkn, koruyan ve gelecek nesillere doğru aktaran toplumlar kendi özünü kaybetmeden kendini geliştirir. Kültürel değerlerin planlı ve programlı bir şekilde bireylere aktarılması ise eğitim sistemiyle gerçekleşmektedir. Eğitim sisteminde temel beceri, tutum ve değerlerin kazandırılmasında ilkokul önemli bir noktadadır. Bu bağlamda değerlerin kazanılmasında kritik bir dönemde olan ilkokul, öğrencilere kültürel değerleri kazandırmak açısından da önem arz etmektedir.

Kültürü meydana getiren değerler, dil ve edebiyat aracilığıyla tanitılır, millete benimsetilir (Özbay, 2002, s.115). Eğitim sisteminde dil becerilerinin kazandırılmasında öncü olan Türkçe dersi kültürel değerlerin kazandırılmasında önemli bir yere sahiptir. Türkçe dersi kapsamında işlenen metinlerle birlikte bireyler, hem dil becerilerini geliştirir, hem de içinde yaşadığ1 toplumun sahip olduğu kültürünü, değerlerini ve özelliklerini öğrenir (Kasa, 2015, s.32). Türkçe ders kitaplarında yer alan metinler kültürel değerlerin aktarımı ve kazandırılması açısından önemlidir. Bu bağlamda araştırmanın amacı ilkokul Türkçe ders kitaplarında yer alan metinlerin kültürel değerler açısından durumunu ortaya koymaktır.

\section{Yöntem}

Çalışmada nitel araştırma yaklaşımı benimsenmiş ve doküman analizi yöntemi kullanılmıştır. Genellikle diğer araştırma yöntemlerini tamamlayıcı özellikte olmasına rağmen, tek başına bir yöntem olarak da kullanılabilen doküman analizi (Kıral, 2020, s.176), araştırılması planlanan olgu ve olgular hakkında bilgi içeren sözlü, yazılı vb. materyallerin incelenmesini kapsamaktadır (Şimşek ve Yıldırım, 2008, s.189). Bu bağlamda araştırmada Türkçe ders kitaplarındaki kültürel değerler incelenmiştir. Türkçe ders kitaplarının seçiminde Milli Eğitim Bakanlığınca onaylı 2020-2021 eğitim öğretim yılında geçerliliğini sürdüren Türkçe ders kitaplarından seçkisiz olarak hepsi farklı yayınevi olmak koşuluyla ilkokul 2, 3 ve 4. sınıf Türkçe ders kitaplarından birer tane seçilmiş ve incelenmiştir. Kitaplarda dinleme metinleri yer almadığ için kitaplardaki her temadan 3 okuma, 1 serbest okuma metni incelenmiş ve toplamda 96 metin analiz edilmiştir. Dinleme metinlerinin sadece 
başlıkları incelenerek bir sınıflama yapılmıştır. İçerik analiziyle analiz edilen verilerden tema ve alt temalar oluşturulmuştur.

Veriler analiz edildikten sonra Türkçe öğretmenliği ana bilim dalında görev yapan bir uzmandan dokümanları analiz etmesi istenmiştir. Oluşturulan temalar bir araya getirilmiş ve görüş ayrılığı olan temalar gözden geçirilip ortak bir nokta belirlenmiştir. Güvenilirlik için Miles ve Huberman (1994, s.64)'ın güvenirlik formülü kullanılmış [Güvenirlik=Görüş Birliği/(Görüş Birliği+Görüş Ayrılığı] ve sonuç olarak araştırmanın güvenirliği .81 olarak hesaplanmıştır. Miles ve Huberman'a göre güvenirliğin 70 üstü çıkması araştırmanın güvenilir olduğunu ortaya koymaktadır. Bu araştırmanın da güvenilir olduğu söylenebilir. Araştırmanın aktarılabilirliğini için de ayrıntılı betimleme yoluna gidilmiştir. Bu bağlamda bulgularda incelenen dokümanlardan elde eidlen verilere ilişkin olarak örnekler verilerek bulgular desteklenmiştir.

\section{Bulgular}

İncelenen ilkokul 2, 3 ve 4. sınıf Türkçe ders kitaplarından elde edilen bulgulara ilişkin tema ve alt temalar Tablo 1'de yer almaktadır. Metinler başlığı altında örnekler 2.5.3 (2. Sınıf 5. Tema 3. Metin), 3.7.4 (3. Sınıf 7. Tema 3. Metin), 4.2.SO (4. Sınıf, 2. Tema Serbest Okuma Metni) şeklinde belirtilmiştir. Ders kitaplarındaki temaların başlıkları ise sırasıyla 2. sınıf Türkçe ders kitabında "Çocuk Dünyası, Milli Mücadele ve Atatürk, Erdemler, Milli Kültürümüz, Doğa ve Evren, Vatandaşlık Bilinci, Sağlık ve Spor, Bilim ve Teknloji"; 3. sınıf Türkçe ders kitabında "Erdemler, Çocuk Dünyası, Milli Kültürümüz, Vatandaşlık, Sağlık ve Spor, Doğa ve Evren, Milli Mücadele ve Atatürk, Bilim ve Teknoloji”; 4. sınıf Türkçe ders kitabında "Okuma Kültürü, Milli Mücadele ve Atatürk, Erdemler, Bilim ve Teknoloji, Doğa ve Evren, Milli Kültürümüz, Sağlik ve Spor, Sanat"tır. Böylelikle yalnızca frekanslar değil frekanslara ilişkin bütün örnekler kitapta yer aldığ 1 tema ve metin sırasına göre Tablo 1'de belirtilmiştir. 
Tablo 1. Bulgulara İlişkin Tema ve Alt Temalar

\begin{tabular}{|c|c|c|c|c|c|c|c|}
\hline Tema & Alt Tema & $\begin{array}{l}\text { 2.Sinif } \\
\text { Metinler }\end{array}$ & $f$ & $\begin{array}{l}\text { 3. Sinif } \\
\text { Metinler }\end{array}$ & $\mathrm{f}$ & 4. Sinıf Metinler & $f$ \\
\hline $\begin{array}{l}\text { Türk Dili } \\
\text { ve }\end{array}$ & Edebi Eserler & 2.4 .4 & 1 & 3.3 .3 & 1 & $4.1 .1,4.6 .3,4.6 .5 \mathrm{SO}, 4.7 .3$ & 5 \\
\hline \multirow[t]{2}{*}{ Edebiyatı } & Yazarlar & 2.2 .3 & 1 & 3.7 .4 & 1 & $4.1 .2,4.2 .3$ & 2 \\
\hline & Atasözleri & 2.6.SO & 1 & - & - & 4.6.1, 4.6.3 & 2 \\
\hline \multirow[t]{11}{*}{ Türk Tarihi } & Tarihi Eserler & - & - & $3.3 .1,3.7 .1$ & 2 & 4.2.1, 4.4.SO & 2 \\
\hline & Tarihi Olaylar & $2.2 .3,2.2 . \mathrm{SO}$ & 2 & $3.7 .1,3.7 .2$ & 3 & $4.2 .2,4.2 .3,4.2 . \mathrm{SO}$ & 3 \\
\hline & Tarihi Kişiler & Atatürk & 2 & Atatürk & 3 & Atatürk & 3 \\
\hline & & $2.2 .2,2.2 . \mathrm{SO}$ & & $\begin{array}{l}\text { 3.7.1, 3.7.2 } \\
\text { 3.7.SO }\end{array}$ & & $\begin{array}{l}\text { 4.2.1, 4.2.2, } \\
4.2 . \mathrm{SO}\end{array}$ & \\
\hline & & Şehitler & & & & Şehitler & 1 \\
\hline & & 2.2.1, 2.2.3 & 2 & & & 4.2 .2 & \\
\hline & & & & & & Diğer Tarihi Kişiler & 4 \\
\hline & & & & & & $4.2 .3,4.2 .4$ & \\
\hline & & & & & & 4.6.SO, 4.7.2 & \\
\hline & & & & & & Bilim İnsanları & \\
\hline & & & & & & $\begin{array}{l}\text { 4.2.SO, } 4,4,2,4.4 .3, \\
4.4 . \mathrm{SO}, 4.5 .1\end{array}$ & 5 \\
\hline \multirow[t]{2}{*}{ Şehirler } & Semboller & $2.4 .1,2.4 .2$ & 3 & 3.3 .1 & 3 & 4.5 .1 & 3 \\
\hline & & & & 3.5.SO & & 4.5.SO, 4.6.1 & \\
\hline \multirow[t]{6}{*}{ Sanat } & Türkü & - & - & - & - & 4.2 .3 & 1 \\
\hline & Sanatçı & - & - & - & - & 4.3.1. & 1 \\
\hline & Spor & 2.7 .3 & 1 & - & - & 4.7 .2 & 1 \\
\hline & El Sanatları & & - & - & - & 4.8 .2 & 2 \\
\hline & Gölge Oyunu & - & - & 3.3.2 & 1 & 4.6.2, 4.8.2 & 2 \\
\hline & Geleneksel Oyun & & & 3.2.4 & 1 & & \\
\hline \multirow{5}{*}{$\begin{array}{l}\text { Bağımsızlık } \\
\text { Simgesi }\end{array}$} & Vatan/Ülke sevgisi & 2.2.1, 2.2.2. & 4 & 3.3.1, 3.7.3 & 2 & $4.2 .2,4.2 .3,4.2 . \mathrm{SO}$ & 5 \\
\hline & & 2.2.SO, 2.4.1 & & & & 4.6.4, 4.6.SO & \\
\hline & Marş & & & 3.7 .4 & 1 & 4.2 .3 & 1 \\
\hline & Bayrak & 2.2.1, 2.2.2. & 3 & $3.3 .4,3.7 .2$ & 2 & - & - \\
\hline & & $2.4 . \mathrm{SO}$ & & & & & \\
\hline \multirow[t]{5}{*}{ Din } & Namaz & - & - & - & - & 4.4 .3 & 1 \\
\hline & Müslümanlık & - & - & - & - & 4.4 .3 & 1 \\
\hline & Ramazan & - & - & 3.4 .1 & 1 & 4.6 .2 & 1 \\
\hline & İnanç & - & - & 3.7 .3 & 1 & 4.6.SO & 1 \\
\hline & Zekat/Sadaka & 2.3.1 & 1 & - & - & & - \\
\hline Gelenek & Konukseverlik & - & - & 3.3 .2 & 1 & 4.6 .3 & 1 \\
\hline \multirow[t]{5}{*}{ Görenek } & Türk kahvesi & - & - & - & - & 4.6 .3 & 1 \\
\hline & Yemek & - & - & 3.3.2 & 1 & & \\
\hline & Milli Birlik & 2.2 .3 & 1 & - & - & 4.2 .3 & 1 \\
\hline & Özel Günler & 2.4 .1 & 1 & - & - & - & - \\
\hline & Anne Sevgisi & 2.4 .3 & 1 & 3.1 .2 & 1 & - & - \\
\hline Toplam & & & 24 & & 25 & & 50 \\
\hline
\end{tabular}

Tablo 1 incelendiğinde Türkçe Ders Kitaplarında yer alan kültürel değerler "Türk Dili ve Edebiyatı", "Türk Tarihi", "Şehirler", "Sanat", "Bağımsızlık Simgesi", "Din" ve "Gelenek-Görenek" olmak üzere 7 temada sınıflandırılmıştır. 
Tablo 1'de "Türk Dili ve Edebiyatı" temasında Edebi Eserler, Yazarlar, Atasözleri olmak üzere 3 alt tema yer almaktadır. Dil, kültürün gelecek kuşaklara aktarımında aracı olan bir kültür aktarıcısıdır. Türkçe dersi ve derste en çok kullanılan kaynak olan metinler dilin özelliklerini kazandırılmasında önemli bir yere sahiptir. Bu bağlamda kültürel değerler açısından da Türk dili büyük bir rol oynamaktadır. Dilin yapısı, dilin zenginlikleri, dile katkısı olan edebi eserler, edebi eserlerin yazarları vb. Türk diline ilişkin kültürel değerlerin kazandırılmasında birer ögedir. Özellikle Türkçe dersinde yer alan metinlerin edebi nitelikleri ve içerisindeki söz varlığının zenginliği başlı başına Türk dilinin zenginliğinin göstergesidir.

Edebi Eserler alt temasında 2. sınıf Türkçe ders kitabında ( $\mathrm{f}=1)$, 3. sınıf Türkçe ders kitabında ( $\mathrm{f}=1)$, 4. sınıf Türkçe ders kitabında ( $\mathrm{f}=5)$ örnekler yer almaktadır. 2. sınıf Türkçe ders kitabındaki Milli Kültürümüz 4. temasında yer alan "Hoca Nasreddin" dinleme metninin, 3. sınıf Türkçe ders kitabındaki Milli Kültürümüz 3. temasında yer alan "Yıldızla Isınmış" okuma metninin, 4. sınıf Türkçe ders kitabındaki Sağlık ve Spor 7. temasinda yer alan "Şifa Niyetine" okuma metninin Nasreddin Hoca'yla ilişkili metinler olduğu görülmektedir. Edebi Eserler alt temasında Nasreddin Hoca'nın fikra anlatım tarzından yararlanarak öğrencilere Türk dilinin özellikleri kazandırılmaya çalışılmıştır.

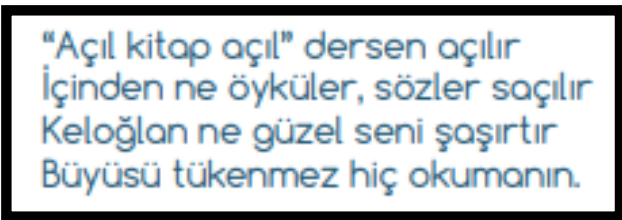

Şekil 1. “4.1.1 Numarah Metin” Edebi Eser Örneği

Resim 1'de görüldüğü gibi 4. sinıf "Kitap Büyüsü" isimli metinde yer alan "Açık kitap açıl” sözünü Binbir Gece Masallarında yer alan Ali Baba ve Kırk Haramiler' de geçen "Açıl susam açıl" sözüyle ilişkilendirilmiş ve "Keloğlan ne güzel seni şaşırtır" derken Keloğlan masallarına gönderme yapılmıştır. 
"Türk Dili ve Edebiyatı" temasında yer alan Yazarlar alt temasında 2. sinıfta Ömer Seyfettin, 3 ve 4. sinıfta Mehmet Akif Ersoy vurgulanmıştır. 2. sınıf Türkçe ders kitabında 2.2.3 "Çanakkale'den Sonra" metninde “...Bu önemli zaferde verdiğimiz şanlı şehitlerimizi her yıl 18 Mart gününde anıyoruz. Bu kutlu zaferi anlatmak için şairlerimiz nice şiir yazdı, nice öykü, roman kaleme alındi. Ömer Seyfettin de 'Çanakkale'den Sonra' isimli hikâyesiyle, bu zaferin verdiği umut duygusunu en güzel şekilde anlatan yazarlardan biri oldu..." geçen sözlerle Türk diline katkıda bulunan yazarlardan Ömer Seyfettin vurgulanmıştır. Bunun yanı sıra örnekte görüldügü gibi hem Türk Tarihi temasındaki Tarihi Olaylar alt temasına ilişkin Çanakkale Zaferi hem de Tarihi Kişiler alt temasına ilişkin şehitlere de vurgu yapıldığı görülmektedir.

4.1.2 örneğindeki "Asım'ın Nesli Kitap Dostudur" metninde ise Mehmet Akif Ersoy "...Akif'in boşa geçirecek zamanı yoktu. O ya okurdu ya okuturdu; ya yürürdü ya da sizi de birlikte yürütürdü. (...) Âkif için cehalet bir tür hastalıktı. Toplum ancak okuyarak cehaletten uzaklaşabilirdi. Bu yüzden Âkif, gençlerin sistemli okumasını ve kendilerini yetiştirmelerini isterdi. (...) Âkif, kalkınmanın cehaletin yenilmesiyle mümkün olacă̆ına inanırdı. İlkokul siralarından başlayarak ilme, fenne ve sanata adım atılmasım isterdi..." şeklinde anlatılmıştır. Örnekte görüldüğü gibi Mehmet Akif Ersoy'un okumaya ilişkin görüşleri vurgulanmış ve metinde bir fotoğrafına yer verilmiştir.

Bir dilin zenginlikleri içinde yer alan atasözleri bir toplumun bilgeliğini, deneyimlerini, yaşantısını, görüşünü ve anlatım gücünü yansıtan sözlerdir (Aksan, 2006, s. 33). Metinlerde yer alan atasözleri Türk dilinin zenginliklerini ve özelliklerini öğrencilere göstermek açısından önemlidir. 2.6.SO örneğinde geçen "Kumbara" şiirinde "Büyükler ne demişler; göl olurmuş damlalar. Azar azar artmalı, çoğalmalı paralar" şeklinde yer alan kıtada hem "Damlaya damlaya göl olur" atasözü vurgulanmış hem de tutumluluk değerine vurgu yapılmıştır. Bunun yanı sıra 4.6.1 "Her Büyük Efsane" isimli metinde "... Bu efsane, babasina bir salkım üzümü çok gören bir oğulu anlatırken; 'Baba oğluna bir bağ bağışlamış; oğul, babasına bir salkım üzüm vermemiş.' atasözünü de açıklamaktadır." örneğiyle atasözüne vurgu yapılmıştır.

"Türk Tarihi" temasında Tarihi Eserler, Tarihi Olaylar, Tarihi Kişiler alt temaları yer almaktadır. Tarihi eserler alt temasında 4.2.1 “Çok Kitap 
Okurdu" metinde geçen "Atatürk bu kitapları dikkatli okumuş, ilgisini çeken noktalara işaretler koymuş ve notlar almıştır. Bu kitaplardan 3123 adedi Anıtkabir Atatürk ve Kurtuluş Savaşı Müzesinde sergilenmektedir..." örneğinde Atatürk'e ait olan kitapların müzede sergilendiği vurgulanmıştır. 3.3.1 "Türkiye'm" şiirinde de "Medeniyet fışkırır topră̆gndan taşından, Selçuk, Efes, Bergama sanki müze doğuştan." dizeleriyle tarihi eserlerden bahsetmektedir.

Tarihi Olaylar alt temasında kitaplarda Çanakkale Savaşı, Kurtuluş Savaşı, 23 Nisan ve 19 Mayıs tarihleri vurgulanmıştır. 3.7.1 "Atatürk'ün Hayatı" metninde geçen "O, her zaman ulusunun özgürlü̈̆̈̈ için çalıştı. Çanakkale Savaşı'nda üstün başarılar gösterdi. Yurdumuza giren düşmanlara karşı Kurtuluş Savaşı'n başlattı. Başkomutanlığııı yaptı̆̆ı bu savaş, zaferle sonuçlandr." örnekte hem Atatürk'e hem de Tarihi olaylardan savaşlara yer verilmiştir. 2.2.SO "Asker Ağlamaz Arkadaş" metninde "Atatürk, 19 Mayıs bin dokuz yüz on dokuzda Samsun'a çıtıktan sonra kentte dolaşır. Halkla görüşmeler yaparken bir yerde üstü başı yırtık, postalları delinmiş bir er hemen dikkatini çeker." örneğiyle Atatürk ve 19 Mayıs 1919 tarihine vurgu yapmiştır.

Tarihi Kişiler alt temasında 2. sınıf Türk ders kitabında Atatürk ( $\mathrm{f}=2)$ ve Şehitler ( $\mathrm{f}=2)$; 3 . sınıf Türk ders kitabında Atatürk ( $\mathrm{f}=3)$; 4 . sınıf Türkçe ders kitabında Atatürk ( $\mathrm{f}=3$ ), Şehitler $(\mathrm{f}=1)$, Diğer Tarihi Kişiler $(\mathrm{f}=4)$ ve Bilim İnsanları ( $\mathrm{f}=5$ ) yer almaktadır. 2. sınıf ve 4 . sınıf "Milli Mücadele ve Atatürk" temasında şehitlerden bahsedilmiştir. Kutsal bir inanış, vatan uğruna canını vermiş kişiler olarak tanımlanabilecek şehitlere ilişkin 2.2.1 "Şehit Mehmet Kamil" metninde "... Mehmet Kâmil, annesinin üstünü aramaya kalkan askere cebinde sakladığı büyük bir taşla vurur. Ardından cebindeki bütün taşlarn askerlere atar. Yere düşen asker, Mehmet Kâmil'in üzerine atılır ve silahıyla onu vurur. Mehmet Kâmil'in annesine son sözü, 'Kaç!' olur. Mehmet Kâmil, Antep şehrinin ilk şehididir. Bu yüzden Gaziantep'teki bir ilçemizin adı 'Şehit Kamil'dir." örneği yer almaktadır.

Tarihi Kişiler alt temasında Atatürk'e ilişkin 3.7.1 Atatürk'ün Hayatı, 3.7.SO Atatürk, 4.2.1 Çok Kitap Okurdu metinlerinde Mustafa Kemal Atatürk'ü doğrudan konu alan ve Atatürk'ün hayatını, özellikleri anlatan örnekler olduğu gibi başka konulardan bahsederken Atatürk'e değinen metinler de söz konusudur. Bunun yanı sıra 4. sınıf Türkçe ders kitabında Yörük Ali Efe, Koca Yusuf, Şerife Bacı gibi tarihte yer alan 
kişilere de değinilmiştir. 4.2.SO metninde Vecihi Hürkuş, 4.4.SO metininde de İbni Sina gibi bilim insanlarından da bahsedilmektedir.

"Şehirler" temasında Semboller alt teması yer almaktadır. Şehirler temasında Türk şehirleri, meşhur simgeleri, özellikleri, geçmişten getirdiği tarihi yapısı vurgulanabilir. 2. sınıf Türkçe ders kitabında "Yerli Malları Tutum Haftası" metninde şehirlerin meşhur meyveleri ve "Kız Kulesi" metninde Kız Kulesinin güzelliği, 3. sınıf Türkçe ders kitabında “Türkiye'm" şiiriyle Türkiye'nin şehirleri, 4. sınıf Türkçe ders kitabında ise Manyas Kuş Cenneti Milli Parkı, Yeşilırmak, Ege Bölgesi gibi yerlere değinerek şehirler temasına ilişkin kültürel değerlerden bahsedilmiştir.

"Sanat" temasında Türkü, Sanatçı, Spor, El Sanatları, Gölge Oyunu ve Geleneksel Oyunlar alt temalarına değinilmiştir. Spor alt temasında yer alan 2. sınıf Türkçe ders kitabında 2.7.3 "Sporcu" metnindeki güreş vurgusu haricinde 2. sinıfta sanat temasına ilişkin kültürel değerler gözlenmemiştir. "Sanat" temasının Türkü alt temasında 4.2.3. "Efelerin Efesi, Hey Gidinin Efesi" metninde Resim 2'de görüldüğü gibi türkü hikâyesine değinilerek türküye vurgu yapıldığ görülmektedir.

Yunanlı komutanlar, bu beklenmedik baskın karșısında paniğe kapıldılar. Baskından kurtulup kaçabilenlerse tası tarağı topladıkları gibi Nazilli’yi terk etmek zorunda kaldılar. Yörük Ali Efe ile arkadaşlarının gösterdiği kahramanlık her yerde duyuldu. Dillere destan oldu. Onun hakkında türküler yakıldı. O türkülerden birinde șöyle deniyordu:

"Șu Dalama'nın çeșmesi

Ne hoş olur içmesi

Yörük Ali'yi sorarsan

Efelerin seçmesi

Hey gidinin efesi

Efelerin Efesi."

(...) Artık bütün Anadolu ayaktaydı. Ayaklanmamış hiçbir yer kalmamıştı.

Memleketin her köşesi umut ve inanç doluydu.

Şekil 2. “4.2.3. Numaralı Metin”-Türkü Örneği

Bunun yanı sıra 4.8.2. "El Sanatlarını Yaşatalım” metninde “...Ebru ustasının yanından ayrılarak Trabzon Hasırı'nın yani 'Telkârinin' yapıldı̆̆ yere gelirler..." şeklindeki açıklama ve metinde yer alan uzun anlatımla Ebru ve Telkâri el sanatlarına dikkat çekilmiştir. 3.3.2 metni "Misafir" ile 4.6.2 metni "Kanlı Kavak" örneklerinde Hacivat ve Karagöz'ün diyalogları yer alarak Türk kültüründe önemli bir yere sahip olan gölge oyunu karakterleri öğrencilere tanıtılmıştır. 
Bir diğer tema olan "Bağımsızlık Simgeleri"nde ise Vatan/Ülke Sevgisi, Marş, Bayrak alt temalarına yer verilmiştir. Vatan/Ülke sevgisine ilişkin 2. sınıf Türkçe ders kitabında $(\mathrm{f}=4)$, 3. sınıf Türkçe ders kitabında $(\mathrm{f}=2)$, 4. sinıf Türkçe ders kitabında $(\mathrm{f}=5)$ örnek söz konusudur. Kitaplarda "Milli Mücadele ve Atatürk" ve "Milli Kültürümüz" temalarında vatan sevgisi genel anlamda vurgulansa da 2.2.SO "Asker Ağlamaz Arkadaş" metninde yer alan "Düşman, ülkemizin her köşesine girdi. Böyle bir zamanda hükûmet beni terhis etti, koyuverdi. Silahımı elimden aldı. Yurdumu nasıl savunacağım, düşmana nasıl haddini bildireceğim?" şeklindeki örnekte vatan sevgisinin direkt aktarıldığ görülmektedir. Resim 3'te görüldüğü gibi 4.2.2 "Atatürk Aralarındaydı" metninde de vatan için mücadele eden askerler yer almakta ve onların "Vatan să̆ olsun, kimseye vermem bir avuç toprağımı" gibi sözleriyle vatan sevgileri gösterilmektedir.

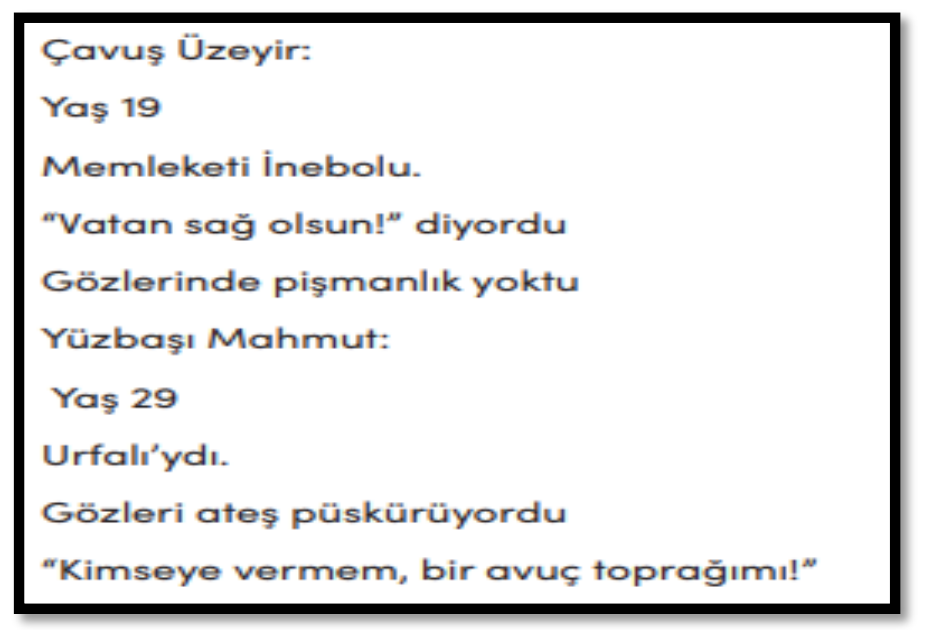

Şekil 3. “4.2.2. Numaralı Metin” Vatan Sevgisi Örneği

Marş alt temasında İstiklal Marşı vurgusu yapılmıştır. Resim 4'te görüldüğü gibi 4.2.3 “Efelerin Efesi, Hey Gidinin Efesi” metninde şanlı mücadele sonunda yazılan İstiklal Marşı'nın tarihi sürecinden bahsedilmiştir. 
Iște bu şanlı mücadelenin şiirini yazmaya gelmişti sıra. Şiir, aynı zamanda İstiklâl Marșımız olacaktı.

Bu amaçla bir yarışma açtı Türkiye Büyük Millet Meclisi. Yarışmayı Mehmet Âkif Ersoy kazandı. Şiiri şöyle başlıyordu:

"Korkma, sönmez bu şafaklarda yüzen al sancak;

Sönmeden yurdumun üstünde tüten en son ocak.

O benim milletimin yıldızıdır, parlayacak!

O benimdir, o benim milletimindir ancak!

Çatma, kurban olayım, çehreni ey nazıı hilal!

Kahraman ırkıma bir gül... Ne bu șiddet, bu celal?

Sana olmaz dökülen kanlarımız sonra helal.

Hakkıdır, Hakk'a tapan, milletimin istiklâl."

Bu dizeler, halkımızın ruhunda yeni ateşler yaktı. Taptaze bir millî inanç ve özgüven yarattı. Anadolu halkı her geçen gün biraz daha birleșiyor, tek yürek tek yumruk oluyor, o yumruk düşmanın tepesine inmek için sabırsızlanıyordu:

"Ya istiklâl ya ölüm!"

\section{Resim 4. “4.2.3 Numaralı Metin” İstiklal Marşı Örneği}

Bayrak alt teması ise 2 ve 3 . sınıf Türkçe ders kitabında yer almıştır. Resim 5'te yer alan 3.7.2 "Gülümsedi Kırmızı" şiirinde hem 23 Nisan Ulusal Egemenlik ve Çocuk bayramı hem de bayrak sevgisi vurgulanmıştır.

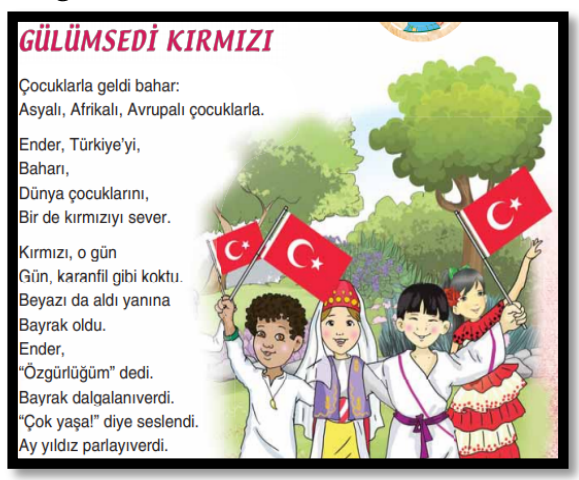

Resim 5: “3.7.2 Numaralı Metin” Bayrak Örneği
Mehmet Kâmil, ok gibi yerinden firladı. Türk bayrağını yere doğru atan askerin yanından hızla geçti. Bayrağı yere düșmeden yakaladı. Kızgınlıkla ve hiçbir șey düșünmeden bağırdı:

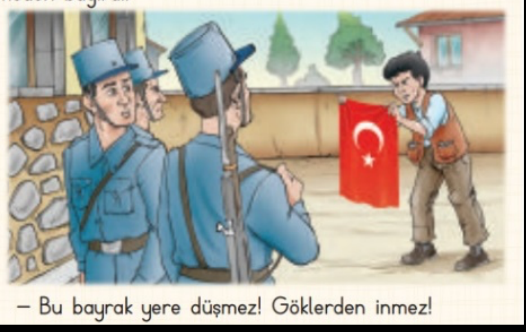

Resim 6: "2.2.1 Numaralı Metin" Bayrak Örneğ $i$

Bağımsızlık simgelerinden biri olan bayrak, Türk kültüründe çok önemlidir. Türk bayrağının şeklinin ortaya çıkışı çok anlamlıdır ve Türk halkı bayrağına saygı duyar, bayrağını asla yere düşürmez. Resim 6'da 
da görüldüğü gibi şehit Mehmet Kamil'in düşman askerine karşı Türk bayrağını nasıl savunduğu ve Türk bayrağının kutsallığı yer almaktadır.

Özen (2014, s.65)'e göre Türklerin milli benlik kazanmalarını sağlayan ve değerlerini oluşturan kavramlardan biri de din olgusudur. $\mathrm{Bu}$ bağlamda din olgusu da Türk toplumunun kültürel değerlerini oluşturur. "Din" temasında Namaz, Müslümanlık, Ramazan, İnanç, Zekât/Sadaka alt temaları vurgulanmıştır. 2. sınıf Türkçe ders kitabında Zekât/Sadaka alt temasına ilişkin olarak şu örnek verilebilir:

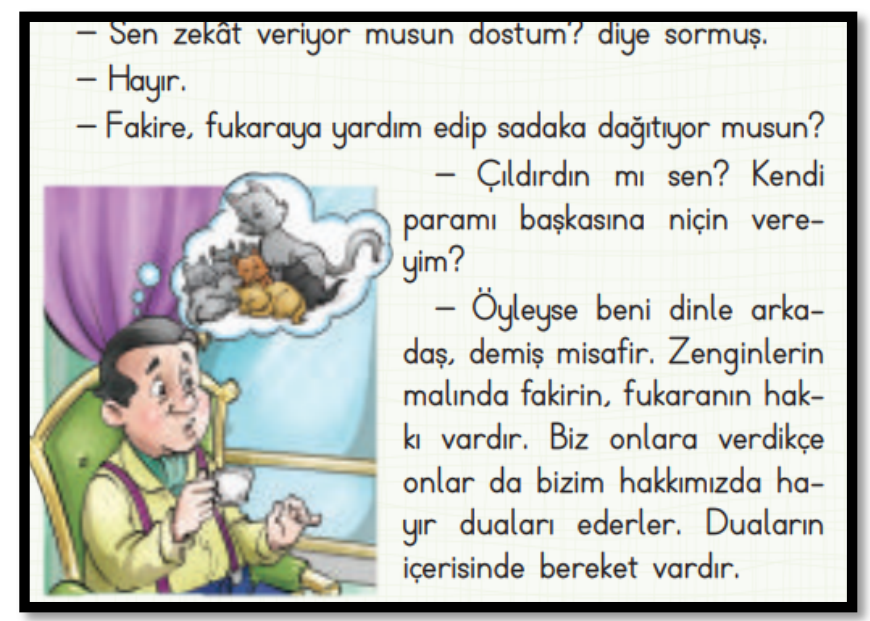

Resim 7: “2.3.1 Numaralı Metin” Zekât/Sadaka Örneği

Resim 7'de görüldüğü gibi zekâtın ve sadakanın öneminden bahsedilmektedir. Cimriliğin olumsuzlukları ve zekât, sadaka vermenin önemi vurgulanmıştır. 3.4.1 "Buğday Masalı" metninde "Ramazanda beyaz pide, yiyemedim yazı deme. Firınlardan çok taze al, sen ikram yap misafire" dizeleriyle Ramazan ayına değinilmiştir. 4.6.SO metninde İnanç temasında "... Oğuz Kağan yurdunu, oğulları arasında paylaştırdı. Son olarak şunları söyledi: Ey oğullarım! Ben çok yaşadım. Çok savaşlar gördüm. Yay ile çok oklar attım. Atla çok yolculuk yaptım. Düşmanlarımı ă̆latıp dostlarımı güldürdüm. Sanırım Gök Tanrı'ya borcumu ödedim. Sizlere de yurdumu veriyorum. Bu yurdun kımmetini bilin, aranızda birlik olun, düşmana firsat vermeyin." örneğiyle Eski Türklerdeki Gök Tanrı inanc1; 4.4.3 metninde Namaz ve Müslümanlık alt temasında "Müslümanlar için zamanın takibi 
çok önemliydi. Çünkü her namazın bir saati vardl. Bunun için Cezeri bir saat tasarlamıştı." örneğiyle bilim insanlarından Cezeri tanıtılırken Müslümanlıkta namazın önemi vurgulanmış.

Son tema olan "Gelenek-Görenek" temasında Konukseverlik, Türk Kahvesi, Yemek, Milli Birlik, Özel Günler, Anne Sevgisi alt temalarına değinilmiştir. 4.6.3 "Bir Fincan Kahve" metninde "Anadolu'nun geleneksel konukseverliği dillere destandır. Ne var ki, bu konukseverlik önce kahveden başlar. Sizi bir acı kahve içmeye çağıran dostunuza neden 'acı kahve' diyemezsiniz. Bu acılıkta, yillar yılı sürecek bir tatllık, yakın bir dostluk vardır. Bu yüzden Anadolu'da 'Bir fincan kahvenin kırk yıl hatırn vardır!' sözü, her yerde, her zaman söylenir durur." Türk konukseverliği, Türk kahvesinin Anadolu'daki önemi açıklanırken atasözüyle bu özellikler vurgulanmıştır. Bunun yanı sıra Türklerin milli birlik duygusundan, Yerli Malı haftası kutlamalarından, anne sevgisinin kutsallığından bahsedilmiştir. Milli birlik alt teması için Resim 8 örneği verilebilir.

"Bu düzen, bu millet birdenbire nereden doğuvermiști, anlamiyordu. Çanakkale'de bir milyonluk düșman ordusu denize sürüldü, büyük zırhlılar battı. Onun ümitsizliği geçtikçe gözleri açllyordu. Artık yașayan bir milletin içinde olduğunu görüyordu. Iște ümidini kestiği bir grup sonunda bir millet oluyordu. Türklerin arasında da bir is birliği fikri doğuyordu."

Resim 8. “2.2.3 Numaralı Metin” Milli Birlik Örneği

Resim 8'de 2.2.3 “Çanakkale'den Sonra" metninde görüldüğü gibi Türklerin Çanakkale Savaşı'nda gösterdiği mücadeledeki milli birlik ve beraberlik vurgulanmaktadır.

\section{Tartışma ve Sonuç}

İlkokul Türkçe Ders Kitapları kültürel değerler açısından incelendiğinde "Türk Dili ve Edebiyatı, Türk Tarihi, Şehirler, Sanat, Bağımsızlık Simgesi, Din ve Gelenek-Görenek" temaları oluşturulmuştur. Kasa (2015)'nın 4. sınıf Türkçe derslerindeki kültürel değerlere ilişkin yaptığı araştırma- 
da da dil, din, edebiyat, tarih, sanat, şehir, gelenek-görenek, bağımsızlık simgeleri boyutunda Türkçe dersinde kültürel değerlere değinildiği gözlenmiştir.

"Türk Dili ve Edebiyatı" temasında Edebi Eserler, Yazarlar, Atasözleri; "Türk Tarihi” temasında Tarihi Eserler, Tarihi Olaylar, Tarihi Kişiler; "Şehirler" temasında Sembolleri; "Sanat" temasında Türkü, Sanatçı, Spor, El Sanatları, Gölge Oyunlar, Geleneksel Oyunları; "Bağımsızlık Simgesi" temasında Vatan/Ülke Sevgisi, Marş, Bayrak; "Din" temasında Namaz, Müslümanlık, Ramazan, İnanç, Zekat/Sadaka; "Gelenek-Görenek" temasında ise Konukseverlik, Türk Kahvesi, Yemek, Milli Birlik, Özel Günler, Anne Sevgisi alt temalarına yer verilmiştir. Özenç ve Orhan-Karsak (2019) araştırmalarında ilkokul ikinci sınıf Türkçe ders kitabında milli-kültürel kavram olarak insan ilişkileri, aile, şehirlerimiz, tarihi şahsiyetler, mekanlar, bayrak, tarihi eserler, büyüklerimiz, Türk, İstiklal Marşı, Anadolu, yurt, vatan, dini bayramlar, gelenekler, milli bayramlar, geleneksel sporlar, Türkçe ve göç kavramlarını ortaya koymuşlardır. Doğan ve Gülüşen (2011)'in araştırmalarında 6,7 ve 8 . sınıf Türkçe ders kitaplarında en çok ulusal değerlerin incelendiğini belirterek ulusal değerleri Atatürk sevgisi, bayrak sevgisi, Türk büyüklerine saygı, kültürel miras, bayramlar, vatan, millet sevgisi gibi değerler olduğunu vurgulamışlardır. Aral (2008)'ın araştırmasında ise 6. sınıf Türkçe ders kitabında en çok işlenen değerlerin vatanseverlik, sevgi, sayg1 ve dini duygular olduğu görülmüştür. Firat ve Mocan (2014)'ın çalışmasında 6, 7 ve 8. sınıf Türkçe ders kitapları değerler boyutunda incelenmiş ve milli değer olarak bir tane anadili sevgisi kavramı tespit edilmiştir. Çalışmalarda görüldüğü gibi metinlerde değerlere yer verilse de kültürel değerler aktarımı istenilen düzeyde değildir. Bu araştırmada da her sınıf düzeyinde kültürel değerler görülse de değerlerin sınıf düzeyine göre farklılaştığı, bazı değerlerin bazı sınıf düzeyinde yer almadığı, en çok 4. sınıf Türkçe ders kitabında kültürel değerlerin yer aldığı ancak yine de istenilen düzeyde olmadığı sonucu görülmektedir.

"Türk Dili ve Edebiyatı" temasında az da olsa atasözlerinin kitaplarda yer aldığı sonucuna ulaşılmıştır. Güftâ ve Kan (2011)'ın 7. sınıf Türkçe ders kitabındaki metinleri incelediği araştırmasında da atasözlerine çok az yer verildiği sonucuna ulaşılmıştır. Girmen (2013)'e göre Türkçe 
derslerinde değer aktarımında atasözleri önemli bir yere sahiptir. Bu bağlamda metinlerde daha çok atasözlerine yer verilerek hem dile ilişkin önemli bir yere sahip olan atasözleri öğrencilere tanıtılır hem de değer aktarımı gerçekleştirilebilir.

Araştırmada "Türk Tarihi" ve "Bağımsızlık Simgesi" temalarına ilişkin tarihi eserler, olaylar, kişiler, vatan sevgisi, marş ve bayrak alt temaları ortaya çıkmıştır. Ekinci-Çelikpazu ve Aktaş (2011)'ın araştırmalarında 6, 7 ve 8 . sınıf Türkçe ders kitaplarını değerler boyutunda incelemiş ulusal değerler açısından vatan sevgisi, millî kimliğini tanıma ve kültürel mirasa ve tarihe duyarlılık değerleri ilk sıraları alırken dil bilinci oluşturma, bayrak sevgisi, ulusal bayramları bilme ve ulusal marş bilinci değerlerinin iletiminin istenen düzeyde olmadığı görülmüştür. Bu çalışmadaki sonuç araştırmanın kültürel değerin istenilen düzeyde olmaması sonucuyla örtüşmektedir. Ancak genel anlamda bakılacak olursa incelenen Türkçe ders kitaplarında en çok Türk Tarihi kültürel değerine vurgu yapıldığı da görülmektedir. Vatan sevgisine ilişkin olarak her sınıf düzeyinde az da olsa vurgu yapıldığ 1 görülmektedir. Susar Kırmızı (2014)'nın araştırmasında da ilkokul 4. sınıf Türkçe dersi kitabına bakıldığında en çok vurgulanan değerlerden birinin millet sevgisi olduğu sonucuyla araştırmadaki vatan sevgisi alt teması benzerlik göstermektedir. Temizkan, Yırtıcı ve Ergün (2020) araştırmalarında 6, 7 ve 8 . sınıf Türkçe ders kitaplarında değerlerin yer alma sıklığına bakıldığında en fazla tekrar edilen değerlerin vatanseverlik, millî değer, gelenek ve görenekler olduğunu belirtmişlerdir. Baki (2019) ortaokul Türkçe ders kitaplarının değer aktarımını incelediği araştırmasında Millî Mücadele ve Atatürk temasında vatanseverlik ve aile birliğini en fazla yer verilen değerler olarak vurgulamıştır. Bu çalışmalar araştırmanın vatan sevgisi alt teması ve gelenek görenek temasıyla benzerlik göstermektedir.

Araştırmanın sonuçları incelendiğinde Türkçe ders kitaplarındaki metinlerde kültürel değerlerin hem dağılım olarak hem sayısal olarak istenilen düzeyde olmadığı görülmektedir. Bu bağlamda araştırmaların sonuçlarına ilişkin olarak şu öneriler verilebilir:

- Türkçe ders kitaplarındaki metinler kültürel değer aktarımı açısından gözden geçirilebilir. 
- Metinlerde yer alan değerlerin dağılımlarına dikkat edilerek her sınıf seviyesinde kültürel değerlerin yeterince vurgulanması sağlanabilir.

- Yayınevlerinin tema ve metin seçimleri değişkenlik gösterse de Türk kültürüne ait kültürel değerlerin öğrencilere kazandırılması için metinler özenle seçilebilir.

- Bu çalışmada her sınıf düzeyinde farklı bir yayınevinin kitabı incelenmiştir. Yayınevlerinin kitapları bütün sınıf düzeylerinde incelenerek kültürel değer aktarımına ilişkin daha detaylı sonuçlar ortaya koyulabilir. 
EXTENDED ABSTRACT

\title{
Cultural Values in the Texts in Primary School Turkish Course Textbooks
}

\author{
Başak Kasa Ayten \\ İnönü University
}

Values are the criteria and standards that unite individuals in the society at a common point, shape the behavior of individuals, direct individuals towards the good and the right, and are formed as a result of common experiences. A value according to Demirhan İşcan (2019, p.31); It should be chosen freely and the benefits of its consequences, transformed into behavior, take its place in life and obtain the approval of the society it will affect. Values accepted and internalized by the society serve to hold the society together and ensure the continuity of the society. Similar values will be accepted by societies and sometimes values may vary from society to society. The peculiar characteristics of a society are revealed only when it comes together with other societies, and non-common and incompatible features show themselves (Aksan, 2008, p.17). This situation is a cultural conflict and it emerges with the conflict of values (Erkılıç, 2019, p.31).

Language, history, ethics, customs and traditions, feelings and thoughts, family, kinship, religion, government, dressing, settlement, art, science, education, morality, technology, are cultural elements that constitute economic culture (Uygur, 2007, p. 56; Güvenç, 2002; Torun, 2006, p. 24). These cultural elements both protect the past and shape the future of the society and form its identity. From the language of the society to its religion, from historical artifacts to historical events, from food to clothing, all living cultural elements constitute the society's own cultural values (Kasa Ayten, 2019, p.308). Language, history, literature, Turkish music, Turkish plastic arts, Turkish cities are also cultural values of Turkish society (Kaplan, 1987). The transfer of cultural values to individuals in a planned and programmed manner takes place through the education system. The Turkish course, which is a pioneer in the acquisition of language skills in the education system, has an important place in 
gaining cultural values. The texts in Turkish textbooks are important for the transfer of cultural values. In this context, the aim of the study is to reveal the status of the texts in the primary school Turkish textbooks in terms of cultural values.

In the study, qualitative research approach was adopted and document analysis method was used. Although it is generally complementary to other research methods, document analysis, which can also be used as a stand-alone method (Kiral, 2020, p.176), contains information about the facts and facts planned to be investigated. It covers the examination of materials (Şimşek and Yıldırım, 2008, p189). In this context, cultural values in Turkish textbooks were examined in the research. In the selection of Turkish textbooks, they were selected randomly from Turkish textbooks approved by the Ministry of Education, which continue to be valid in the 2020-2021 academic year. A total of 3 books were examined from primary school 2nd, 3rd and 4th grade Turkish textbooks, each of them from a different publishing house. Since there are no listening texts in the books, 3 readings and 1 free reading texts were examined from each theme in the books, and a total of 96 texts were examined. A classification was made by examining only the titles of the listening texts. Themes and sub-themes were created from the data analyzed with content analysis. The themes were supported by giving examples from the books in the findings.

When primary school Turkish textbooks are examined in terms of cultural values, the themes of "Turkish Language and Literature, Turkish History, Cities, Art, Symbol of Independence, Religion and TraditionCustoms" have been created. In her research on the cultural values in 4th grade Turkish lessons, Kasa (2015) also observed that cultural values were mentioned in the Turkish lesson in terms of language, religion, literature, history, art, city, tradition-custom, symbols of independence. In Özenç and Orhan-Karsak's (2019) research, in the second grade Turkish textbook of primary school they introduced, human relations as a national-cultural concept, family, cities, historical figures, places, flags, historical artifacts, our elders, Turkish National Anthem, Anatolia, home, homeland, concepts of religious festivals, traditions, national festivals, traditional sports, Turkish and immigration. Doğan and Gülüşen (2011) emphasized that national values are mostly examined in 6th, 7th and 8th 
grade Turkish textbooks, and that national values are values such as love of Atatürk, love of flag, respect for Turkish elders, cultural heritage, festivals, homeland and nation love. In Aral's (2008) research, it was seen that the most processed values in the 6th Grade Turkish Textbook are patriotism, love, respect and religious feelings. In the study of Firat and Mocan (2014), 6th, 7th and 8th grade Turkish textbooks were examined in terms of values and concept for the love of mother tongue was determined as a national value. As seen in the studies, although values are included in the texts, the transfer of cultural values is not at the desired level. In this study, although cultural values are seen at every grade level, it is seen that the values differ according to the class level, some values are not included at some grade level, and the cultural values are mostly included in the 4 th grade Turkish course book but still not at the desired level.

It has been concluded that proverbs on the theme of Turkish Language and Literature are given in books, even if a little. In the research of Güftâ and Kan (2011) examining the texts in the 7th grade Turkish textbook, it was concluded that proverbs were rarely included. According to Girmen (2013), proverbs have an important place in value transfer in Turkish lessons. In this context, by including more proverbs in the texts, the proverbs, which have an important place in the language, are introduced to the students and value can be transferred.

In the research related to the themes of History and Symbol of Independence, historical artifacts, events, people, patriotism, anthem and flag subthemes have emerged. Ekinci-Çelikpazu and Aktaş (2011) examined the 6th, 7th and 8th grade Turkish textbooks in terms of values, while the values of "patriotism", "recognition of national identity" and "sensitivity to cultural heritage and history" ranked first in terms of national values. It has been observed that the transmission of the values "creating awareness of language", "love of the flag", "knowing national festivals" and "national anthem awareness" are not at the desired level. The result of this study coincides with the result that the cultural value of the research is not at the desired level. However, in general terms, it is seen that the Turkish textbooks examined mostly emphasize the cultural value of History. It is seen that there is a little emphasis on love of homeland at every grade level. In the research of Susar-Kirmiz1 (2014), when the fourth 
grade Turkish course book of the primary school is examined, it is similar to the sub-theme of patriotism in the study, with the result that one of the most emphasized values is the love of the nation. Temizkan, Yirtic1 and Ergün (2020) stated that the most frequently repeated values in the 6th, 7th and 8th grade Turkish textbooks were patriotism, national values, traditions and customs. Baki (2019) highlighted patriotism and family unity as the most frequently mentioned values in the theme of the National Struggle and Atatürk in research, in which the value transfer of secondary school Turkish textbooks examined. These studies show similarities with the sub-theme of love for homeland and the theme of tradition.

\section{Kaynakça/ References}

Aksan, D. (2006). Türkçenin sözvarlığı. Ankara: Engin Yayınevi.

Aksan, D. (2008). Türkçeye yansıyan Türk kültürü. Ankara: Bilgi Yayınevi.

Aral, D. (2008). Millı Ĕ̆itim Bakanlığı'nın hazırladığı 6. sınıf Türkçe ders kitabında yer alan değerler üzerine bir araştırma. (Yayımlanmamış Yüksek Lisans Tezi). Abant İzzet Baysal Üniversitesi, Bolu.

Baki, Y. (2019). Ortaokul Türkçe ders kitaplarındaki metinlerin değer aktarımı açısından incelenmesi. Değerler Eğitimi Dergisi, 17(37), 109146.

Demirhan-İşcan,C. (2019). Değerler eğitiminde temel kavramlar. F. Ersoy ve P. Ünüvar (Der.). Karakter ve değer eğitimi içinde (s.31-50). Ankara: Anı Yayıncilik.

Doğan, B. ve Gülüşen, A. (2011). Türkçe ders kitaplarındaki (6-8) metinlerin değerler bakımından incelenmesi. Sosyal Bilimler Dergisi, 1(2), 75-102.

Ekinci-Çelikpazu, E. ve Aktaş, E. (2011). MEB 6, 7 ve 8. sınıf Türkçe ders kitaplarında yer alan metinlerin değer iletimi açısından incelenmesi. Turkish Studies, 6(2), 413-424.

Erkılıç, T. A. (2019). Değişim ve değerler eğitiminin gerekçeleri. F. Ersoy ve P. Ünüvar (Der.). Karakter ve değer eğitimi içinde (s.1-30). Ankara: Anı Yayıncilik.

Fırat, H. ve Mocan, A. (2014). Türkçe ders kitaplarındaki hikâyelerde yer alan değerler. Türkiye Sosyal Araştırmalar Dergisi, 183(183), 25-49.

Girmen, P. (2013). Türkçe eğitiminde atasözleri ve değer eğitimi. Değerler Eğitimi Dergisi, 11(25), 117-142. 
Güftâ, H. ve Kan, M. O. (2011). İlköğretim 7. sınıf Türkçe ders kitabının dil ile ilgili kültürel ögeleri açısından incelenmesi. Mustafa Kemal Üniversitesi Sosyal Bilimler Enstitüsü Dergisi, 8(15), 239-256.

Güvenç, B. (2002). Kültürün ABC'si. (2. Bask1). İstanbul: Yapı Kredi Yayınları. Kaplan, M. (1987). Türk milletinin kültürel değerleri. Ankara: Kültür ve Turizm Bakanlığı Yayınları.

Kasa, B. (2015). İlkokul dördüncü sınıf Türkçe dersinde kültürel değgerler ve eğitimi: Bir durum çalışması. (Yayımlanmamış Doktora Tezi). Anadolu Üniversitesi, Eskişehir.

Kasa Ayten, B. (2019). Türk kültür ve eğitim tarihinde değer eğitimi. F. Ersoy ve P. Ünüvar (Der.). Karakter ve değer eğitimi içinde (s.307-322). Ankara: Anı Yayıncilik.

Kıral, B. (2020). Nitel bir veri analizi yöntemi olarak doküman analizi. Siirt Üniversitesi Sosyal Bilimler Enstitüsü Dergisi, 15, 170-189.

Kurt, N. F. (2004). Dil-kültür ilişkisi ve Cumhuriyet yenileşmeciliği bağlamında dil-kültür ilişkisi. (Yayımlanmamış Yüksek Lisans Tezi). İstanbul Üniversitesi, İstanbul.

Miles, M. B. ve Huberman, A. M. (1994). Qualitative data analysis: An expanded sourcebook. (2. Edition). California: SAGE Publications.

Özbay, M. (2002). Kültür aktarımı açısından Türkçe öğretimi. Türk Dili, 602, 112-120.

Özen, Y. (2014). Türk milli kültüründe değerler ve değerlerin milletleşmeye etkisi. Hikmet Yurdu Düşünce-Yorum Sosyal Bilimler Araştırma Dergisi, 7(14), 59-87.

Özenç, E. G. ve Orhan-Karsak, H. G. (2019). İlkokul birinci ve ikinci sınıf Türkçe ders kitaplarında milli ve kültürel kavramlara yer verilme durumu. Değerler Eğitimi Dergisi, 17(37), 349-379. DOI: 10.34234/ded.547761.

Özkul, O. (2013). Kültür ve küreselleşme. İstanbul: Açılım Kitap.

Susar Kırmızı, F. (2014). 4. sınıf Türkçe ders kitabı metinlerinde yer alan değerler. Değerler Ĕ̆itimi Dergisi, 12(27), 217-259.

Temizkan, M., Yırtıcı, E. ve Ergün, A. (2020). Türkçe ders kitaplarında sosyal değerlerin görünümü. Uluslararası Türkçe Edebiyat Kültür Eğitim Dergisi, 9(2), 769-794.

Tezcan, M. (1987). Kültür ve kişilik (Psikolojik antropoloji). Ankara: Bilim Yayınları. 
Torun, E. (2006). II. Dünya savaşı sonrası Türkiye'de kültürel değişimler: Iç̧ ve dış etkenler, 1945-1960. Antalya: Yeniden Anadolu ve Rumeli Müdafaa-i Hukuk Yayınları.

Uygur, N. (2007). Kültür kuramı. İstanbul: Yapı Kredi Yayınları.

Yıldırım, A. ve Şimşek, H. (2008). Sosyal bilimlerde nitel araştırma yöntemleri (6. Baskı). Ankara: Seçkin Yayıncılık.

\section{Kaynakça Bilgisi / Citation Information}

Kasa Ayten, B. (2021). İlkokul Türkçe ders kitaplarındaki metinlerde kültürel değerler. OPUS-Uluslararası Toplum Araştırmaları Dergisi, 18(40), 2168-2190. DOI: 10.26466/opus.902826. 